\title{
SIMPLIFYING SANSKRIT
}

\author{
Adi Hastings
}

\begin{abstract}
Sanskrit has long been a medium of scholarly, religious, and literary discourse throughout the South Asian subcontinent. But recently, several organizations, imagining Sanskrit as the future lingua franca and emblem of an ermergent Hindu nation, are attempting to turn Sanskrit into a truly "popular" language by encouraging the use of what they call "simple Sanskrit" in everyday conversational contexts. This essay examines several of the semiotic processes involved in simplifying Sanskrit. Specifically, it discusses first the ways in which simple Sanskrit is regularized in order to produce a language which bears many structural similarities to modern Indian vernaculars. Second, the essay turns to a discussion of what simple Sanskrit represents: Through simplification, Sanskrit becomes an icon for the purported democratizing goals of the spoken Sanskrit movement. Sanskrit also represents a tangible index for aspiring speakers, projecting backward to an archaic Golden Age, but also looking forward to an imagined future. These processes have important implications for understanding the role of language ideologies and their effects in the manufacture and maintenance of linguistic identities.
\end{abstract}

Keywords: Sanskrit, Simplification, Language ideology, Language revival.

\section{Introduction}

"Grrhe grhe, grāme grāme, nagare nagare" ("In each home, in each village, in each town"). ${ }^{2}$

${ }^{1}$ Versions of this essay were presented on panels at the annual Conference on South Asia in Madison, WI (October 2002) and at the annual meeting of the American Anthropological Association in New Orleans, LA (November 2002). I would like to thank the organizers of each of those panels, Hans Hock and Janina Fenigsen, respectively. In addition, Jillian Cavanaugh, Victor Friedman, Susan Gal, Julie Hastings, John Kelly, Emily McEwan-Fujita, Robert E. Moore, Michael Silverstein, and Daniel Suslak each read one or many versions and contributed valuable comment and criticism. I would like to thank especially Paul Manning, who supplied constructive input on an early draft. Thanks are also due to the patience and enthusiasm of the members of the Sanskrit conversation classes I attended in Bangalore in late 2000 and early 2001. All errors in fact or interpretation are, of course, my own.

2 Orthographic note: Transliteration of Sanskrit follows standard practice. A macron over a vowel (e.g., $\bar{a}$ ) indicates a long vowel; an $h$ following a consonant indicates aspiration; $c$ is an unvoiced palatal stop; $t$ and $\underset{o}{d}$ are retroflex stops; $s$ and $\propto$ are retroflex and palatal sibilants, respectively; $r$ is vocalic; $\tilde{n}, \tilde{n}$, and $n$ are velar, palatal, and retroflex nasals; $m$ indicates generally nasalization of the preceding vowel, although it is often realized as a homorganic nasal in consonant clusters; $h$ is a voiced aspirant (unlike English), whereas $h$ is an unvoiced aspirant, traditionally pronounced with a faint echo of the preceding vowel. Otherwise, values roughly approximate those in English orthography. One may consult any of the many introductory Sanskrit 
This was the slogan repeated again and again as several hundred activists and enthusiasts gathered in Shimoga, a town in the South Indian state of Karnataka, to celebrate the "South Indian Sanskrit House Festival" in late December 2000. The festival had been organized by Samskrita Bharati, one of the leading organizations in a movement which seeks to revive Sanskrit and make it the popular lingua franca of India, uniting a nation beset by linguistic, religious, social, and ethnic divisions. Although it has remained until recently largely peripheral to the public consciousness except as a curiosity, recent political developments, most notably the simultaneous rise of the Hindu nationalist Bharatiya Janata Party (BJP, "Indian People's Party") to national power, have given the movement new impetus. New educational and cultural programs emanating from New Delhi, such as attempts to introduce compulsory Sanskrit language education, a university degree program in Vedic astrology, and programs to find modern applications for ancient Hindu sciences, have focused renewed attention on the movement to spread conversational Sanskrit. Sanskrita Bharati must be understood as part of this larger social and political context, enmeshed in the resurgence of Hindu nationalism as a new ideological force, especially in the last decade of the twentieth century.

Originally founded in Bangalore by a group of graduates from one of India's Sanskrit universities, the organization began activities in 1981 as part of a Bangalore-based service organization and affiliate of the Hindu nationalist Rashtriya Swayamsevak Sangh (RSS, "National Volunteer Corps"). ${ }^{3}$ In the mid-nineties, they reorganized, in the process incorporating a number of other organizations working for the revival of Sanskrit in various parts of the country, moving their national headquarters to Delhi, and taking the new name of Samskrita Bharati (samskrtabhāratī, "Sanskrit Cultivation" is one of several possible translations) ( Krş̊̊a Eāstrī 1996).

At the Sanskrit House Festival in Shimoga, the organizers devoted the better part of a day to testimonials from people who had made Sanskrit their "home language." Time and again, the audience heard tales of how the speakers had thought Sanskrit was a difficult language - until, that is, they learned Sanskrit through Samskrita Bharati. The basic principle underlying Samskrita Bharati's pedagogical philosophy is that listening and speaking must precede reading and writing. ${ }^{4}$ Eschewing both Western-style Classical grammatical instruction (or more recent innovations) and Indian traditions of Sanskrit instruction, Samskrita Bharati instead has focused its energies on immersion through conversation. This takes the form, most notably, of ten-day Sanskrit conversation camps. These camps have garnered for the organization a great degree of public notoriety and coverage in the Indian and international press and have proved largely popular. According to their own figures, repeated often in their promotional literature, by 1998, 2.9 million people had attended the conversation camps (Samskrita Bharati 1998). Samskrita Bharati coordinates a number of other activities, such as more advanced Sanskrit conversation

textbooks for a more complete description.

${ }^{3}$ The RSS and the BJP together form a substantial part of the so-called Sangh Parivar, a network of organizations in India devoted to the social, political, and cultural cause of Hindu nationalism. Sanskrit (and more recently Sanskrit revival) have always received at least token support from these organizations, and often much more than that. Space does not permit a full analysis of these issues here, however. See Hastings (2004) for an extensive discussion of the relationship between Hindu nationalism and Sanskrit.

${ }^{4}$ For their general approach to language pedagogy, see Krsna CEāstrī (2000a). 
camps and correspondence courses, training courses for spoken Sanskrit instructors, the publication of a monthly Sanskrit magazine, the establishment and maintenance of Sanskrit-speaking households, and their association with so-called "Sanskrit" villages in Karnataka and Madhya Pradesh. Despite recent attempts to shift from the broad horizontal coverage of the ten-day camps to a more organicist approach (see Hastings 2004), the camps remain one of Samskrita Bharati's hallmarks.

The other major component of Samskrita Bharati's revival program is the particular variety of Sanskrit it promotes, called "simple Sanskrit." Given popular understandings of Sanskrit, the vaguely oxymoronic title for this variety of the language is intentional: One of the primary goals of the movement is to demonstrate both how Sanskrit is not, contrary to common belief, a difficult language to learn, and how it can be used in everyday, prosaic contexts of social interaction. Listening to the testimonials at the Sanskrit House Festival, they appear to be having modest success in getting this across. Simple Sanskrit differs in several interesting ways from Classical Sanskrit, and one of the goals of this essay is to review exactly what some of those are. I do so largely by following the course of a typical ten-day Sanskrit conversation camp. But simple Sanskrit is not just about simplifying the grammar, since it doubles as a potent symbol for the ideas and practices of the movement as a whole. Therefore, in the second part of this essay, I examine the significance of what simplifying the language actually means. As I will demonstrate, simple Sanskrit is underwritten by an ideology which I am calling "archaizing modernism," its object being Sanskrit grammatical form, projected as the authentic structure of an ancient Hindu language, but inflected with modernist conceptions about what that ought to be.

The creation of what Samskrita Bharati calls "simple Sanskrit" (sarala-samskrtam) has involved a great deal of thought and effort. It is not "simplified Sanskrit" (saralikrtam samskrtam), as they are quick to point out in conversations and promotional materials. And indeed, rather than providing a reduced or stripped-down grammar, simple Sanskrit exploits existing means of periphrasis to express a variety of grammatical categories. For the most part, grammatical categorial distinctions are maintained; the difference between simple Sanskrit and its Classical counterpart is in the surface-structural realization of these categories. ${ }^{5}$ One major result of these efforts has been the radical regularization of inflectional paradigms across a variety of form classes. As I will discuss below, this, combined with several other features of simple Sanskrit serve to make it resemble much more many of the modern languages of contemporary India. In this way, the "simple" of simple Sanskrit points to the fact that it is designed to act as a bridge between the modern vernacular(s) a simple Sanskrit learner already knows and, ideally, acquisition of the fullyelaborated Classical Sanskrit grammar.

I should emphasize here that what Samskrita Bharati refers to as "simpli fied Sanskrit" would be a variety of the language subjected to formal simplification, a sort of "pidginization" whereby the number of actual grammatical categories (as expressions of relationships between constituents of a phrase) is reduced or delimited. Conversely, "simple Sanskrit" is a variety of the language which has been subjected to what we could call distributional simplification. That is, almost all of the differences between simple Sanskrit and Classical Sanskrit are differences in the distribution of forms rather than grammatical

\footnotetext{
${ }^{5}$ Presentations of the various prescriptions on simplification can be found in Dikshita (1995), and Krsna Eāstrī (1999, 2000b).
} 
categories. Most of the simplifications are, in fact, collocations and periphrastic expressions which are authorized by and present in the Sanskritic textual tradition, to one extent or another, but with sometimes vastly different distributions of token occurrences. So, hereafter, when I refer to "simplification," it is primarily in this sense of distributional simplification.

\section{The conversation camp}

As I noted above, the primary means of popularization of simple Sanskrit which Samskrita Bharati employs has been the sambhāsana-œibira "conversation camp." In their canonical form, these programs run for ten days, with two hours of instruction a day. Formally similar to rapid Berlitz-style language instruction, the camps aim to introduce the participants, most of whom have never studied Sanskrit before, to the basic categories and rules of (simple) Sanskrit grammar, as well as a limited repertoire of vocabulary. This is done by immersion through conversation, with Sanskrit almost the exclusive medium of instruction, and the regional language employed in limited cases to explain more abstract grammatical concepts or to give lexical equivalents when these are not readily apparent or demonstrable through ostensive reference. ${ }^{6}$ The goal is to enable participants to begin using Sanskrit as quickly as possible, usually by the end of the first day of the camp, with the idea that the key to acquisition is frequency of use.

The conversation camps have been one of the primary sources of notoriety for Samskrita Bharati (and related organizations), and enormous emphasis has been placed by the organization on these events as the main site of production for incipient Sanskrit speakers, acting as a gateway for further involvement with the language. Thus, when I first visited the Samskrita Bharati compound after arriving in Bangalore, one of my first questions was whether any camps were planned for the near future or currently in progress. As luck would have it, they told me that there was a camp starting up in a neighborhood nearby in a couple days' time.

The camp was being held in the house of a woman named Sushila, in Hanumanthanagar, a neighborhood in southwestern Bangalore. ${ }^{7}$ The neighborhood is fairly mixed in terms of caste and class, and most of the residents live in modest low-rise apartment buildings on quiet, tree-lined lanes off the main thoroughfares. Although narrow and lined with a chaotic assortment of tea stalls, vegetable stands, pharmacies, clothing outlets, appliance stores, and a scooter dealership, even the main roads running through Hanumanthanagar are relatively peaceful by Bangalore standards, with none of the noise, congestion, and smog which characterize the streets toward the center of the city. Sushila's flat is at the top of a narrow flight of stairs, above a Bangalore City Corporation worker's dispensary. The first time I visit, only Sushila and her family are there. It is early evening,

\footnotetext{
${ }^{6}$ In camps I participated in, all in and around Bangalore, the regional language used was Kannada, a member of the Dravidian family of languages. Since Samskrita Bharati was originally founded in Bangalore, the simple Sanskrit it promotes exhibits a number of "Dravidianisms" (see Hastings 2004 for discussion).

${ }^{7}$ While what follows is based largely on one of the camps I attended in Bangalore, elements of other events have been incorporated for expository purposes.
} 
and they are sitting around the TV, watching an old Rajkumar movie from the 60s. The people I spoke to at Samskrita Bharati had said that the eibira would be starting today, but I quickly discover that this is not, in fact, the case. Rather, it will be starting next week. Nonetheless, Sushila invites me to stay for tea, and sends her daughter out to fetch someone.

Sushila's daughter returns with a young woman, in her early 30s, who is introduced to me as Rohini. It turns out she is actually the person who has organized the conversation camp. I tell her that I am doing research on spoken Sanskrit, and wanted to sit in on the camp they were having. Rohini had attended a camp back in the late 1980s with some of her school friends. She had tried to keep up the practice of speaking Sanskrit, but had, over the course of time, ceased to do so. So this camp she was organizing was going to be a refresher course for herself, as well as an opportunity for others to learn the language for the first time. Rohini had gathered together several interested people from the neighborhood, and they would all be doing the camp together.

I return to Hanumanthanagar the following week for the first day of the eibira. It is early evening when I arrive, and most of the participants are already there. ${ }^{8}$ They include Sushila and her ten-year-old daughter, Gita, Rohini, her husband, Vishvas, and their son, Sudhir, four adult women and two men, who are neighbors, and several younger boys and girls from the neighborhood, ranging in age from five to twelve. The instructor sent by Samskrita Bharati, Mohan, arrives, and introductions are made. I have seen Mohan once or twice at Aksaram (the Samskrita Bharati compound in Bangalore), but never actually met him before.

The class begins, as they always do, with a Sanskrit song. The songs vary from camp to camp, but a single song will be used consistently throughout the course of a particular camp, sung at the beginning and end, as a ritual book-end for each session. In this way, Sanskrit is invoked from the very opening of the session. On the first day of this camp, Mohan, standing at the front of the room, begins singing a song venerating Sarasvati, the goddess of knowledge (and by extension, Sanskrit), a popular subject of songs sung in Sanskrit conversation camps. After the first couple of choruses, other people in the room start joining in, and by the end of the song, everyone is singing.

As the song concludes, Mohan begins with the lesson. He points to himself, saying, "Mama nāma mohanah" ("My name is Mohan"). He then points to Rohini's husband, "Bhavatah nāma kim?" ("What is your name?"). Vishvas hesitates, and Mohan repeats the statement and then the question. "Mama nāma vioevās," is the reply. Mohan corrects him, adding a Sanskritizing ending to his name, "Viœvāsah. Bhavatah̆ nāma viœvāsah." Mohan repeats this process with a couple of the younger boys, who answer with less trepidation than Vishvas. He then points to Sushila, " Bhavatyăh nāma kim?" emphasizing the long vowel in the final syllable of the first word. "Mama nāma suœ $\overline{1} \bar{a}, "$ she answers, supplying the correct ending (zero) for her (grammatically feminine) name. Mohan continues this way until all the participants have had a chance to be asked and give an answer.

This basic routine for asking one's name and the reply introduces participants to several features of Sanskrit: One of the basic clause structures for questions and statements, the distinction between masculine and feminine (and secondarily, neuter) grammatical

\footnotetext{
${ }^{8}$ The camp is being held in the evenings since many of the participants work during the day. This is fairly normal, although sometimes the 10-day course will be crammed into a solid two or three days.
} 
gender, and the use of the genitive case (sasthi-vibhakti). All this is done entirely through the medium of Sanskrit and, following Samskrita Bharati's general practice and philosophy, done without any explicit metapragmatic characterizations of the grammatical phenomena being demonstrated. That is, never once during this routine does Mohan explain what it is that he is doing or give a gloss, either in Sanskrit or some other language. ${ }^{9}$ For our purposes, there are two things we should note here about simple Sanskrit from these basic sentences: The lack of external sandhi and the forms used as second-person pronouns.

One of the most readily noticeable differences between Classical Sanskrit and simple Sanskrit, both in speaking and to a greater extent in writing, is the almost complete absence of external sandhi in simple Sanskrit. Sandhi (literally, "juncture") is the cover term for euphonic combination and coalescence found in inflectional and derivational processes (internal sandhi) and at word boundaries (external sandhi). ${ }^{10}$ External sandhi is particularly vexing for new learners of Sanskrit, since it obscures word boundaries and, because it applies in cyclical fashion, can operate in some phonological contexts until there is very little resembling the underlying words left at all.

While maintaining the full complement of word-internal sound processes, simple Sanskrit dispenses almost entirely with external sandhi, with several minor exceptions observed primarily in writing. In this respect, simple Sanskrit is very much like a padapātha ("word-teaching") version of a text, used in perduring traditions of Sanskrit textual transmission, where each word is uttered as if alone, isolated from any surrounding phonological context. Thus, for example, the following verse (1) from the Bhagavadgit $\bar{a}$ (3.38) would be rendered under Classical Sanskrit sandhi rules as (1'):

dhåmena āvriyate vahnih / yathā ādarœap malena ca // yathā ulbena āvrtaho garbhaho / tathā tena idam āvrrtam // 3.38

"As fire is covered by smoke, as a mirror by dust, as an embryo is covered by the womb, so is this covered by that."

$$
\begin{aligned}
& \text { dhåmenāvriyate vahnir / yathādarœo malena ca // } \\
& \text { yatholbenāvrọto garbhas / tathā tenedam āvrọtam // }
\end{aligned}
$$

In simple Sanskrit, the sentence would remain almost exactly as given in (1). There are, however, two exceptions to this general avoidance of external sandhi, which are more obviously relevant to writing than speaking. The first exception is the formation of anusvāra at the end of words $(/ \mathrm{m} /$, technically a nazalization of the preceding vowel, but usually realized in speech as [ $\mathrm{m}]$ ). As applied on word boundaries, it is a relatively straightforward rule $\left(\mathrm{m} \rightarrow \mathrm{m} / \_\# \mathrm{C}\right)$ and universal in its application. The second exception has to do with the leftward spread of voicing to unvoiced final consonants. This rule also

9 A popular aphorism among the revivalists is "conversation should not be about Sanskrit; conversation should be made with Sanskrit" [samskrtasya visaye bhāsanam na, samskrtena sambhāsanam kartavyam] (Krşna EEāstrī 1996: 4).

${ }^{10}$ For detailed discussions of sandhi in Sanskrit, see Allen (1962) and Emeneau (1958). The phenomenon is so pervasive in Sanskrit that the Sanskrit term has been adopted in linguistics as a technical term covering this sort of phenomena cross-linguistically. 
applies in all cases. The continuing applicability of these rules, where other rules have been ignored, largely has to do with the fact that their application makes little apparent difference in speaking. Even in writing, the functioning of these two rules does not significantly obscure word boundaries. There are also a small number of lexicalized exceptions, almost all entailing the coalescence of $/ a /$ in commonly used phrases: e.g., tathāpi (tath $\bar{a}+a p i$ "yet"), nāsti (na + asti "is not"), māstu (māa + astu "let not").

In the routine introduced by Mohan, the avoidance of external sandhi can be seen in the form of the words used for the second-person possessive, bhavatah (masculine) and bhavatyăh (feminine). If external sandhi were being observed, these words would be pronounced as bhavato and bhavatyā, respectively, since they are followed by a word beginning with a voiced segment. What is also interesting about this routine is the fact that the words used for second-person forms are, in fact, not pronouns at all. Simple Sanskrit proscribes the use of the entire second-person pronominal paradigm, using instead the noun bhavān/bhavatī "your honor" (masc./fem.). ${ }^{11}$ These are used in place of second-person pronouns, with a third-person verb. This has the added effect, as I discuss below, of entirely removing second-person forms from verbal conjugational paradigms, as well. The rationale usually given is that bhavān is a "polite" form of address, a fact that is amply attested in the Sanskritic textual tradition (see Ananthanarayana 1985; Van de Walle 1993). However, with no alternative form, since the entire second-person pronominal and verbal paradigms are dropped, with no axis of selection based on contextual determinants like "power" and "solidarity" (Brown and Gilman 1960) - unlike modern Hindi, for example, wit thtum/āp ${ }^{12}$ - bhavān ceases pragmatically to be a polite form, and instead assumes the role of the second-person pronoun. ${ }^{13}$

After making sure everyone understands this initial structure, Mohan moves on to demonstrating the use of various pronominal forms, such as sah, sā, tat ("he/she/it," also doubling as distal pronominal masc./fem./neut. adjectives, i.e., "that"), and their relative (yah, ya, yat) and interrogative counterparts $(\mathrm{kah}, \mathrm{k} \bar{a}, \mathrm{kim})$. The first day also covers several classes of indeclinables ( avyaya-s), such as the adverbials atra, tatra, yatra, and kutra ("here," "there," "where," and "where?"), as well as several other commonly used particles (ām "yes," na "no/not," etc.). In introducing these elements, Mohan adopts the same strategy as before: "Aham mohanah. [Pointing to me] Esah ādih. [Pointing to Vishvas] Sah $k a h$ ? [Pointing to Gita] Să $k \vec{a}$ ?" ("I am Mohan. This is Adi. Who is he? Who is she?").

Several common verbs are also introduced on the first day. Mohan uses sample sentences and some amount of ostensive gesturing to indicate the distinctions between singular 1st and 3rd person forms of present (or more technically, non-past) indicative verbs, as well as 3rd person imperative forms. By the end of the first day, the participants are beginning to have a feel for some of the basic principles of (simple) Sanskrit grammar, and have a very limited inventory of vocabulary. They are able to put together basic sentences, such as, "mama lekhanī kutra asti?" (Where is my pen?) and "œvah atra

11 The forms encountered in the routine above, bhavatah/bhavatyāh, are the genitive case form of these nouns.

12 The "intimate," "neutral," and "polite" second-person pronouns, respectively.

13 This was, interestingly, one of the most difficult adjustments for me to make in my own Sanskrit. I was never able to ascertain with clarity whether my interlocutors thought I was being rude or that I just did not know any better. 
āgacchatu" ("Come here tomorrow").

The second day is largely occupied with introducing two grammatical concepts: Plurality, in both nominal and verbal inflection, and the locative case. Again, with the verbs, second person forms are entirely left out. As I discuss below, the dual, as a grammatical category for nouns and verbs, is also discarded in simple Sanskrit, so that for any present indicative verbal conjugation paradigm, a student of simple Sanskrit need only learn four, rather than nine forms. In example (2), below, I have given the paradigm for the conjugation of $\sqrt{ } \mathrm{gam}$ "go." The forms in black are the forms retained in simple Sanskrit, while those in grey are not used.

$$
\begin{aligned}
& \text { Present indicative of } \sqrt{ } \text { gam "go" } \\
& \text { sg } \quad \mathrm{du} \quad \mathrm{pl} \\
& \text { 1st gacchāmi gacchāvaho gacchāmah } \\
& \text { 2nd gacchasi gacchathah gacchatha } \\
& \text { 3rd gacchati gacchatah gacchanti }
\end{aligned}
$$

For imperative forms, the task is made even simpler. Without 2 nd person or dual number forms, the learner of simple Sanskrit need only master the 3rd person singular and plural forms (for $\sqrt{ }$ gam "go": gacchatu and gacchantu). ${ }^{14}$

When introducing the locative case, Mohan employs several sample sentences, usually involving body parts (e.g., "Mama haste lekhan $\overline{1} a s t i, "$ "The pen is in my hand"). Sanskrit traditionally inflects nouns to express eight different kinds of case relationships: Nominative, accusative, instrumental, dative, ablative, genitive, locative, and vocative. One of the distinctive characteristics of simple Sanskrit is the extent to which emphasis has been placed on expressing many of the oblique cases by means of periphrasis. ${ }^{15}$ Participants have already learned the genitive and nominative cases, and the locative is the first nominal case that they learn which can be optionally be expressed by means of periphrasis. ${ }^{16}$ Locative case marking is periphrastically indicated through the suffixing of either of two elements, -madhye "middle (loc sg)" or -samipe "near (loc sg)." These elements will be affixed to an uninflected noun stem, forming a compound. Thus, a sentence such as (3), would be realized as (3'), using -madhye.

$$
\begin{aligned}
& \text { grhe asmi } \\
& \text { house (loc sg) be (1st sg pres) } \\
& \text { "I am in [my] house." }
\end{aligned}
$$

$$
\text { grha-madhye asmi }
$$

\footnotetext{
${ }^{14}$ Classical Sanskrit does have a full paradigm for the imperative, however 1st person forms are not included in the taught grammar of simple Sanskrit. Also note that the imperative is where one would perhaps be most likely to encounter 2nd person forms, and I have one attestation from a published article written in simple Sanskrit.

${ }^{15}$ See Speijer (1990: 113-178) for a catalogue of the various kinds of periphrastic expression of case relations in Classical Sanskrit grammar.

${ }^{16}$ In fact, the locative is encountered in both spoken and written discourse as much with an inflectional case-marking as with a lexical one. In the conversations and texts I have analyzed, this largely seems to correlate with whether the noun is from a regularly encountered form-class (e.g., $a$-stem nouns), where inflection will usually be employed, or not.
} 
house-middle (loc sg) be (1st sg pres)

The participants in the conversation camp practice using the locative with a variety of bodily and institutional locations. Over the next several days, Mohan introduces a number of other means of periphrasis for indicating nominal cases, and I will review those here.

To indicate the ablative case, an extremely productive method used in Classical Sanskrit, and adopted in simple Sanskrit, is the use of the adverbial suffix -tah (-tas) (see Speijer 1990: 68; Taraporewala 1967: 43). Sentence (4) as rendered with ablative casemarking, would appear in simple Sanskrit as (4') by this means.

$$
\begin{array}{lc}
\text { grāmād } & \text { āgacchati } \\
\text { village (abl sg) } & \text { come (3rd sg pres) } \\
\text { "[He] comes from a village." }
\end{array}
$$

(4') grāma-tah āgacchati

village-(abl) come (3rd sg pres)

This is an extremely common method employed in simple Sanskrit. Another method encountered occasionally compounds the base noun with nimittam "motive, cause (acc sg)" for the indication of ablative case-marking.

For indicating instrumental case, the noun is compounded with - $d v \bar{a} \bar{a} \bar{a}$ "means" $\left(d v \bar{a} r+\right.$ inst sg) ${ }^{17}$ A sentence such as (5) below, with the noun simply inflected in the instrumental case, would be rendered by this means as (5'), with - $d v \bar{a} r \bar{a}$ affixed to the uninflected noun-stem.

$$
\begin{array}{ll}
\text { lekhanyā } & \text { likhāmi } \\
\text { pen (inst sg) } & \text { write (1st sg pres) } \\
\text { "I write with a pen." }
\end{array}
$$

$$
\begin{array}{ll}
\text { lekhanī-dvārā } & \text { likhāmi } \\
\text { pen-by means of (inst sg) } & \text { write (1st sg pres) }
\end{array}
$$

The use of this sort of periphrasis is, as far as I can tell, relatively less frequent than some of the periphrastic expressions used for other cases. Many speakers appear to have a reasonably full command of the instrumental paradigms. This may be due largely to the fact that one of the main occurrences of the instrumental case is to mark the logical subject of a passive verb. ${ }^{18}$

For the dative, there are a couple of options. The most common is the compounding

\footnotetext{
${ }^{17}$ Note that most accounts of this periphrastic expression (e.g., Apte 1965, s.v. " $d v \overline{a r a m} "$; Speijer 1990: 141) mention the use of the neuter nominal stem $d v \bar{a} r a$ - in the instrumental ( $d v \bar{a} r e n a)$, rather than the feminine stem $d v \bar{a} r$ - (cf. Dikshita 1995: 72). Preference for this form is surely influenced by modern Hindi usage, where the postposition $d v \bar{a} r \bar{a}$ is a common means of indicating instrumentality.

${ }^{18}$ Although simple Sanskrit does away almost entirely with the passive verb paradigm, it can still be indicated by relatively common passive participial forms (see below).
} 
of the noun with -krte "for, for the sake of" (from past participle of $v k r$ "do": $k r t a+l o c s g$ ). This is found relatively frequently in later stages of Classical Sanskrit, where krte is often also used as an indeclinable particle, modifying a nominal stem in the genitive (a slightly different phenotypic actualization of the same grammatical relationships, note). A sentence such as (6) would be rendered as (6') by this means.

$$
\begin{array}{ll}
\text { bhiksukāya } & \text { dadāti } \\
\text { beggar (dat sg) } & \text { give (3rd sg pres) } \\
\text { "He gives to the beggar." }
\end{array}
$$

$$
\begin{array}{ll}
\text { bhiksuka-krte } & \text { dadāti } \\
\text { beggar-sake (loc sg) } & \text { give (3rd sg pres) }
\end{array}
$$

In a parallel fashion, one can indicate the dative case by using -arthe "for the sake of, for" (from artha "aim, purpose, meaning" + loc sg).

Marking genitive case relationships does not receive the affixation treatment that other oblique cases do, partly because the genitive is the most commonly used of all the oblique cases, and thus worth memorizing whatever its irregularities, and partly because, as may be evident, compounding two words is an extremely productive way of indicating the genitive (it may also indicate almost any other case relation, but again, the genitive is by far the most common).

About half-way through the course, participants learn the way of indicating the fact that there are two of some noun. In Classical Sanskrit, this is normally done with the dual. It is infrequently encountered, and the the most atrophied of all the nominal paradigms (in that there is the greatest overlap and ambiguity of inflectional endings). In simple Sanskrit, as I have already said, the dual number is entirely absent, both in nominal and verbal paradigms. Rather, to indicate duality, as with the other means of periphrasis, one affixes a lexical element to the uninflected noun stem, in this case - dvayam "pair," and any predication is indicated with a singular verb. ${ }^{19}$ Thus, the Classical Sanskrit sentence in (7) would appear as (7') in simple Sanskrit:

$$
\begin{array}{lll}
\text { panditau } & \text { pustakam } & \text { pathatah } \\
\text { pandit (nom du) } & \text { book (acc sg) } & \text { read (3rd du pres) } \\
\text { "The two pandits read a book." } &
\end{array}
$$

$$
\begin{array}{lll}
\text { pandita-dvayam } & \text { pustakam } & \text { pathati } \\
\text { pandit-pair (nom sg) } & \text { book (acc sg) } & \text { read (3rd sg pres) }
\end{array}
$$

On Day 3 of the camp, we are introduced to ways of forming the past tense in simple Sanskrit. This is where, distributionally, perhaps, simple Sanskrit diverges most from its Classical counterpart. That is, with the exception of the commonly-employed verb roots $\sqrt{ }$ as "be" and $\sqrt{ }$ bhå "be, become," which are taught as finite verbs conjugated in the imperfect (e.g., 3rd sg impf: $\bar{a} s \bar{t}$, abhavat), simple Sanskrit relies exclusively on the use of

\footnotetext{
${ }^{19}$ Note, as with most of these lexical affixes, -dvayam is surface-segmentable, linearly continuous, semantically compositional, etc. (see Silverstein 1981).
} 
participial forms. Specifically, simple Sanskrit employs the past active and past passive participles, the former constructed by adding a highly regular attributive suffix to the latter. Neither inflects for differences between first, second, and third person objects. For the past active participle, instead of multiple past tense paradigms, students of simple Sanskrit need only learn the following paradigm (which is exactly the same as the paradigm for bhavān):

(8) Past active participle endings

$\begin{array}{lll} & \text { Singular } & \text { Plural } \\ \text { Masc./neut. } & - \text { vān } & \text {-vantah } \\ \text { Feminine } & - \text { vat } \overline{1} & \text {-vatyah }\end{array}$

Thus, instead of saying a sentence such as (9), one can express it as (9'), and the participle will be the same whether it is referring to a 1st, 2nd, or 3rd person:

$$
\begin{array}{lll}
\text { aham } & \text { rāmāyanam } & \text { apatham } \\
\text { I (nom sg) } & \text { Ramayana (acc sg) } & \text { read (1st sg impf) } \\
\text { "I read the Ramayana." } &
\end{array}
$$

$$
\begin{array}{lll}
\text { aham } & \text { rāmāyanamo } & \text { pathavān } \\
\text { I (nom sg) } & \text { Ramayana (acc sg) } & \text { read (nom sg) }
\end{array}
$$

Throughout the remainder of the ceibira, participants are taught several other verbal derivatives, such as the gerund, the gerundive, and the infinitive, all of which are highly regular, surface-segmentable, and are not inflected for person or number.

At the end of the ten days, the participants have a reasonable command of many basic features of (simple) Sanskrit and can formulate a wide variety of expressions. On the last day, after the class is finished, they have a small party where friends and neighbors are invited. The members of the camp have been practicing several Sanskrit skits and songs over the last few days and perform these for the audience. I am asked to speak, which makes me nervous, since this is my first occasion of public Sanskrit speaking. Several representatives from Samskrita Bharati show up and exhort the members of the camp and the rest of the assembled audience to pursue Sanskrit with diligence (primarily through the variety of other activities that the organization sponsors; see Hastings 2004 for details).

\section{The meaning of simple Sanskrit}

As I have already suggested, a primary rationale for simple Sanskrit's distributional "refocusing" of Sanskrit grammar in this way is ease of acquisition. The paradigms become shorn of many of their irregularities and the total number of forms which need to be learned for any word is drastically reduced. To further reduce the learning load, the lexicon is selected so as to provide the greatest regularity in inflection. With nominal stems, this results in an increased preference for $-a$ stems (the most common and most regular), over consonantal stems, especially, which are introduced where necessary as peculiar exceptions. Verbal roots are limited primarily to those in thematic classes (i.e., those roots which take a thematic vowel), while others which are commonly used (such as $\sqrt{k r}$ "make, do") are 
introduced as exceptions. Overlaid on top of this is a marked preference for lexical items which have some isomorphic (and usually historically related) realization in modern Indian languages, usually either Hindi or the regional language.

The end result of this is to make the line between simple Sanskrit and modern Indian languages remarkably vague in some places. Some of the means of periphrasis employed in simple Sanskrit in fact parallel (or incorporate) historical developments in the modern Indo-Aryan languages (and especially Hindi). So, with postposed case marking elements (according to Chatterji (1960), actually a development in Middle Indo-Aryan languages, later incorporated in Sanskrit), or the heavy reliance on participial forms for verbs, or the particular vocabulary selected, students of simple Sanskrit find a great deal of the language strikingly familiar. As I suggested earlier, much like MoliŠre's Monsieur Jourdain discovering that he had been speaking prose all his life, the average Indian participant in the conversation camps discovers that they have, in fact, been speaking Sanskrit all their life.

But while there is an explicit pedagogical rationalization for simple Sanskrit, it is also subject to simultaneous, and possibly contradictory, valorizations. On the one hand, the strategies of simplification are directed toward returning the language to an imagined pristine state, a purity and simplicity in the distant past now obscured by centuries of pedantic obfuscation. On the other hand, the simplifications are informed by a fully modernist aesthetic, one which prizes a one-to-one relationship between grammatical form and function, between token lexical form and denotatum. This is what I mean by an ideology of "archaizing modernism" (cf. Subramaniam 2000) which underwrites simple Sanskrit.

The spoken Sanskrit revivalists claim Sanskrit to have been the popular and prosaic language of communication in the distant past. In doing so, they imagine ancient India as a unitary and homogeneous cultural and linguistic entity. Sanskrit was then and will be in the future the language of all Indians irregardless of any prior caste, ethnic, religious, or linguistic affiliations, they assert. As a model for this simple language, they point to the conversational style of Patañjali's Mahābhāsya ("Great Commentary") on Pāninini, or the language of the Pañcatantra (a collection of fables) or the great epics. Only subsequently, they claim, was the language made the exclusive property of a scholastic elite; divorced from quotidian life the language became complex, with multi-constituent compounds and a (needless) profusion of synonyms. The revival then, is really framed as a return, a return to something lost that must be found again.

But the means by which they go about making Sanskrit simple is informed by distinctly modernist conceptions about what language is for and what it ought to look like. While the language and style of Patañjali or the Pañcatantra may be invoked as exemplars of the kind of prosaic Sanskrit which is their target, a more accurate model is perhaps BASIC (British-American-Scientific-International-Commercial) English. Developed during the heyday of the auxiliary language movements in the first half of the twentieth century by C. K. Ogden and I. A. Richards, BASIC English was the result of its inventors' attempts to purge the "emotive" aspects of language, leaving behind a rationalist base (see Silverstein 2001). The English lexicon was reduced to a register of 850 lexical primes, combinations of which, it was claimed, could express any thought. A precise and unambiguous correspondence of signifier and signified would enable clear and easy communication. In discussions of simple Sanskrit, BASIC English is constantly invoked 
(e.g., Dikshita 1995, Krssna CEāstrī 2000b - who even states that simple Sanskrit could be called Basic Sanskrit ${ }^{20}$ as a model..$^{21}$ And, for example, with the regularization of nominal case-marking through the use of postpositions discussed above, we can see the way in which there is a trend toward the creation of a fixed and unambiguous one-to-one correspondence between grammatical form and function. In addition, in Samskrita Bharati's view, despite energetic attempts to highlight the historical and symbolic associations of Sanskrit, conversation ultimately comes down to a utilitarian need to communicate some meaning to some hearer, and the most efficient way to do this is with "simple" language: "Generally, we do not say the ?The child drinks water [dimbah kilălam pibati]? when we mean ?The child drinks water [œiœuh jalam pibati].? Language is naturally simple" ( Krsno Eāstrī 2000b: 28; see also Krssna CEāstrī 1999: 40). ${ }^{22}$ The import here is twofold. Most explicitly, we ought to use more prosaic vocabulary (the latter) rather than obscure or poetic vocabulary (the former) if we want to communicate more effectively. But this also suggests that the "simple" vocabulary is somehow more naturally meaningful, or is perhaps simple precisely because of its natural meaningfulness.

However, as I mentioned earlier, these so-called simplifications are not recent innovations in the language, although we could probably say that their token frequencies are. This is what I mean by archaizing modernism. Simple Sanskrit is archaic in form, since it entails little innovation in underlying grammatical categorial structure, but modern in distribution since it entails innovation in the modulus signatures of those categories by democratically expanding the "simplest" forms to all contexts of occurrence (Whorf 1956 [1937]). By preserving the overt grammatical categories (such as the eight cases of nominal case-marking), even if emphasizing a different (and highly regular) morphosyntactic expression of these categories, the Sanskrit revivalists are able to hold out the possibility of later eventual acquisition of the full grammar, in all its inflectional glory. Given that one of the main premises of the movement is to allow direct access to the vast storehouse of the Sanskritic textual tradition, this is perhaps not surprising. But by placing so much emphasis on the regularization of the expression of grammatical relations by lexical rather than morphological means, the presence or absence of inflectional morphology becomes enregistered as an index of relative fluency and genre. That is, while graduates of the conversation camps will rely heavily on postpositional case-markers, texts such as the articles in Sambhāsanasandeœah will employ the full complement of nominal inflection and a much wider range of verbal conjugation and derivation. The prominence of inflectional morphology becomes an index for an elaborated, "fancy" register of Sanskrit.

\section{Conclusion}

The simple Sanskrit which Samskrita Bharati promotes through its conversation camps is

${ }^{20}$ atra samskrte api anayā rītyā målabhåtam samskrtam iti kartum ceakyate ( Krșna CĒ̄strī 2000b: 29).

${ }^{21}$ Also note that, according to Raghavan (1972), several different proposals for simplifying Sanskrit were first circulating around in the 1930s, giving an added synchronicity to the connection with auxiliary language movements of the early twentieth century. $\bar{a}$ sahajā.

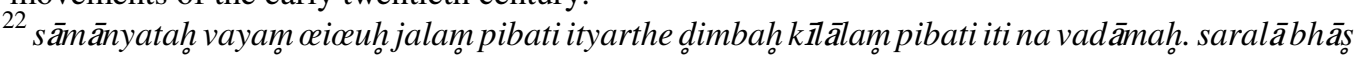


heavily inflected with ideas about what the form and purpose of language is or ought to be. By retaining the formal grammatical apparatus of Classical Sanskrit grammar while altering the distributional expression of grammatical relationships, simple Sanskrit instantiates an ideology of archaizing modernism - an ideology which seeks to project the language back to an idealized Hindu Golden Age while at the same time regularizing and "simplifying" the language. Additionally, since simple Sanskrit conforms to a greater degree with the structures of modern Indo-Aryan vernaculars (and, lexically, to some degree with modern Dravidian languages), learners of simple Sanskrit come away with the impression that Sanskrit truly must be the underlying, unifying language of all Hindus - since they were already practically speaking it without knowing it.

These recent efforts to promote Sanskrit have attempted to divorce the language from its symbolic associations as the high literary language and the property of a closed group of elites, making the language available as an emblem to invoke a generalized, primordial "Hindu" cultural heritage, in effect relocating the center of authority. The language is decentered from its role as one of the authorizing powers for a ritually-based social hierarchy and recentered as a language of politico-religious unification. This move parallels in many ways the invocation of Hindutvā ("Hindu-ness") and the revisioning of a unitary Indian cultural history more generally by Hindu nationalist organizations. Specifically, in seizing upon a vision of a homogeneous Indian history, the teleology of the Indian nation becomes one of a return to an originary, organic unity that had been corrupted by millennia of accreted modifications, or in Gyan Prakash's (1999) felicitous phrase, a vision of the modern nation as a "return to the archaic." Similarly, the archaizing modernism of simple Sanskrit projects a utopian past as the authorizing force behind a future vision of an equally utopian future: An archaic utopia in which access to Sanskrit is generalized across an entire population who use it simply and clearly, and a modernist utopia in which there is a clear one-to-one relationship between form and function.

\section{References}

Allen, W.S. (1963) Sandhi: The Theoretical, Phonemic, and Historical Bases of Word-Junction in Sanskrit. The Hague: Mouton.

Ananthanarayana, H.S. (1985) Expressions of politeness in Sanskrit. Vishveshvaranand Indological Journal 22.1-2: 103-115.

Apte, Vaman Shivram (1965) The Practical Sanskrit-English Dictionary. 4th ed. Delhi: Motilal Banarsidass.

Brown, R., and A. Gilman (1960) The pronouns of power and solidarity. In Thomas A. Sebeok (ed.), Style in Language. Cambridge, MA: MIT Press, pp. 253-276.

Chatterji, Suniti Kumar (1960) Indo-Aryan and Hindi: Eight Lectures Originally Delivered in 1940 before the Gujarat Vernacular Society, Ahmedabad. 2nd ed. Calcutta: Firma K. L. Mukhopadhyay.

Dikshita, Sadananda (1995) Sanskrit as a Modern Language. Puri: Sanskrit Academy of Research for Advanced Society through Vedic and Allied Tradition of India.

Emeneau, Murray B. (1958) Sanskrit Sandhi and Exercises. Rev. ed. Berkeley: University of California Press. 
Hastings, Adi (2004) Past Perfect/Future Perfect: Sanskrit Revival and the Hindu Nation in Contemporary India. Ph.D. dissertation, University of Chicago.

Krssna Eāstrī, Ca. Må (1996) Uditā samskkrtabhāratī. Sambhāsananasandeœaho 2.10: 4-5, 27.

Krssna Eāstrī, Ca. Må (1999) Sañkramanam. 2nd ed. New Delhi: Samskrita Bharati.

Krşna Eāstrī, Ca. Må (2000a) Jñāne dharmah̆ uta prayoge? New Delhi: Samskrita Bharati.

Krsna Eāstrī, Ca. Må (2000b) Saralasamskrtam katham? In Idamittham: Vividhaih vidvadbhih likhitānām bhāss āvisayakalekhānām sañgrahah. 2nd ed. Bangalore: Samskrita Bharati, pp. 28-32.

Prakash, Gyan (1999) Another Reason: Science and the Imagination of Modern India. Princeton: Princeton University Press.

Raghavan, V. (1972) Sanskrit: Essays on the Value of the Language and the Literature. Madras: The Sanskrit Education Society.

Samskrita Bharati (1998) Samskrtam vadatu. New Delhi: Samskrita Bharati.

Silverstein, Michael (1981) The limits of awareness. Sociolinguistic Working Paper, no. 84. Austin: Southwest Educational Development Laboratory.

Silverstein, Michael (2001) From The Meaning of Meaning to the empires of the mind: Ogden's orthological English. In Susan Gal and Kathryn Woolard (eds.), Languages and Publics: The Making of Authority . Manchester: St. Jerome, pp. 69-82.

Speijer, J.S. (1990) [1886]. Sanskrit Syntax. Delhi: Bodhi Leaves.

Subramaniam, Banu (2000) Archaic modernities: Science, secularism, and religion in modern India. Social Text 64: 67-86.

Taraporewala, Irach J.S. (1967) [1937] Sanskrit Syntax. Delhi: Munshiram Manoharlal.

Van de Walle, Lieve (1993) Pragmatics and Classical Sanskrit: A Pilot Study in Linguistic Politeness . Amsterdam: John Benjamins Publishing Company.

Whorf, Benjamin Lee (1956) [1937] Grammatical categories. In John Carroll (ed.), Language, Thought, and Reality: Selected Writings of Benjamin Lee Whorf. Cambridge, MA: MIT Press, pp. 87-101. 